\title{
The recent geodynamics of Haitian migration in the Americas: refugees or economic migrants?
}

\author{
Cedric Audebert ${ }^{\star}$
}

\begin{abstract}
After having presented the specific migration context of Haiti and its multidimensional vulnerability, this paper shows that the diaspora geography explains, to a large extent, the location of Haitian refugees and asylum seekers in North America and the French Caribbean territories. Then, we explore the relation between migration policy evolution and the development of new migration routes towards South America, where the recognition of the multidimensional nature of this migration has paved the way for the legalization of Haitian migrants, particularly in Brazil. The complementary migration functions of Ecuador, Peru, Brazil and Chile created a new regional migration system centered on the Southeast and the South of Brazil. This emerging South-South migration route is part of a larger Haitian migration system that connects Latin America to North America and the Caribbean.
\end{abstract}

Keywords: Migration policy. Refugees. Haitians. Latin America. North America, the Caribbean.

\footnotetext{
*Université de Poitiers, MIGRINTER Research Center, Poitiers, France (cedric.audebert@univ-poitiers.fr).
} 


\section{Introduction}

The complex roots of Haitian emigration have often left the field open to fluctuating and ambivalent migration policies in the countries of destination, considering Haitian migrants alternately as economic migrants or as refugees. Indeed, any reflection on the Haitian refugee issue needs to consider the relation between the multidimensional (economic, ecological, political) vulnerability of local populations in the country of origin, the definition of migration policies in the countries of settlement, and the diversification of migrant destinations abroad. During their migration, individuals may be assigned to several categories, depending on the settlement context, changes in migration policies, and other factors (JACKSON, 2011; AUDEBERT, 2012). In the history of Haitian migration, the line has often remained blurred and oscillating between legal and illegal statuses. On two occasions, this situation has led to the invention of "hybrid" legal categories: the Cuban Haitian Entrant status (1980) was created in the US, in response to the massive infux of boats of people onto Florida shores (STEPICK, 1998), and a humanitarian migrant status was especially designed for recent Haitian migrants coming to Brazil (2012), to address the complex causes of post-earthquake migration from Haiti.

The changing macro-societal context in the country of origin, the permanent inflections of migration policies in the destination countries, and the economic opportunities offered by the employment markets abroad have impacted the geographical reorientation of migrant flows together with the redefinition of migrant categories. In the past few years, the Haitian migration experience has shown how the implementation of more and more restrictive policies in the Northern countries (namely France, the US, and Canada) has contributed to the emergence of new migration destinations in the South. The geographical diversification of Haiti's international migration throughout the 2000s has entered a new phase after the 2010 earthquake. New migratory routes have emerged towards many countries across Latin America (SILVA, 2012; NIETO, 2014; BERNAL CARRERA, 2014; FERNANDES; DA CONSOLAÇAO GOMES DE CASTRO, 2014; VASQUEZ; BUSSE; IZAGUIRRE, 2014; JOSEPH, 2015). The emergence of Brazil as a regional power, its privileged geopolitical relations with Haiti, and the opportunities of its employment market, explain to a large extent why this continental country has rapidly become an important pole of the Haitian diaspora.

After having presented the specific migration context of Haiti, we show that the geography of the diaspora explains the location of Haitian refugees and asylum seekers in North America and the French Caribbean territories. Then, we explore the relationship between the evolution of migration policies and the development of new migration routes towards South America, where the acknowledgment of the multidimensional nature of this migration by the local authorities has paved the way for the legalization of Haitians, particularly in Brazil. The complementary migration functions of Ecuador, Peru, Brazil and Chile created a new regional migration system, centered on the Southeast and the South of Brazil. This emerging SouthSouth migration route is part of a larger Haitian migration system that connects Latin America to North America and the Caribbean. 


\section{Multidimensional vulnerability, Haitian emigration and refugee flows}

The Caribbean Basin remains one of the areas in the world that is the most affected by emigration. According to the International Organization for Migration, five of the ten countries with the highest emigration rates in the world are in this region. In the Greater Antilles, over the 2010-2015 period, the yearly net migration rate ranges from -1.3 per 1000 in Cuba and -2.9 per 1000 in Haiti to -7.0 in Jamaica. ${ }^{1}$ According to World Bank data, 1,377,000 Haitians were living abroad in 2013. ${ }^{2}$ This slightly underestimates the significance of the phenomenon. The actual figure is probably closer to 1.5 million individuals, or the equivalent of 15 percent of Haiti's population (AUDEBERT, 2012). Haitian emigration differs from that of the neighboring countries in volume and in the magnitude of its dispersal in North America, Europe, the Caribbean basin, and increasingly, South America.

This can be explained by a distinctive local context, whose combination of various socioeconomic, political and ecological factors have amplified the dynamics of emigration. In rural areas, demographic pressure on scarce land resources and the extension of erosion have aggravated living conditions among the peasantry (LUNDAHL, 1983; BARTHELEMY, 1990). The process has been reinforced by the persistence of rudimentary agricultural techniques, and the indifference of the ruling classes towards the fate of peasants. This has resulted in the contraction of the arable land, and therefore the reduction of agricultural resources and the impoverishment of the peasantry (ANGLADE, 1982a, 1982b). Over the last three decades, large-scale rural exodus has increased pressure on poorly diversified urban economies, where most of the jobs are in the informal sector. After 1986, the growth of slums and the "ruralization" of cities like Port-au-Prince and, to a lesser extent, Gonaïves and Cap Haïtien, have rapidly changed urban environments, and daily survival strategies have become the norm for a growing share of the population.

In addition, the generalized economic insecurity, which strikes Haiti more than any other nation in the hemisphere, remains intimately linked to various other forms of insecurities that have run through the history of the country. Jointly with demographic and economic structural factors, the succession of major natural disasters over the last ten years (Hurricane Jeanne in 2004, four storms and hurricanes in 2008, and finally the earthquake of 2010) has brought about the extreme vulnerability of the Haitian society. The notion of vulnerability traditionally refers to "the diminished capacities of an individual or group to anticipate, cope with, resist and recover from the impact of a natural or man-made hazard" (INTERNATIONAL ORGANIZATION FOR MIGRATION, 2015). The notion of multidimensional vulnerability goes

\footnotetext{
${ }^{1}$ Source: United Nations Population Division, World Population Prospects: the 2015 revision, custom data acquired via website. Available in: 〈https://esa.un.org/unpd/wpp/DataQuery/〉. The UNPD defines the net migration rate as the number of immigrants minus the number of emigrants over a period, divided by the person-years lived by the population of the country of reference over that period.

2 Source: World Bank bilateral matrix 2013. Available in: 〈http://www.worldbank.org/en/topic/migrationremittances diasporaissues/brief/migration-remittances-datas.
} 
further than this traditional acception, grasping in comprehensive terms the multifaceted character of insecurity in Haiti.

The multidimensional vulnerability considers the interplay between economic, political and ecological dimensions, and gives rise to a broader approach to the notion of insecurity experienced in Caribbean societies. This perspective addresses the uneven social structures inherited from the plantation system, the precarious environmental conditions (i.e. natural disasters and other major hazards on fragile ecological environments), and the recurrent economically and politically driven social crises, closely related to international relations and geopolitical issues in the Caribbean basin.

In this perspective, in order to better understand the dynamics of the Haitian diaspora and its legal implications in the receiving countries, the notion of insecurity on which the following reflection is based, not only refers to immediate life threat issues that are relevant in the definition of the refugee status, but more comprehensively encompasses rule of law, socio-economic, socio-spatial, ecological, political, psychological and humanitarian dimensions. The incidences of the successive events in Haiti's recent history on the diversification of Haitian migration routes in the Americas, including the aftermath of the 2010 earthquake, provide an instructive example of the relationship between environmental insecurity and emigration.

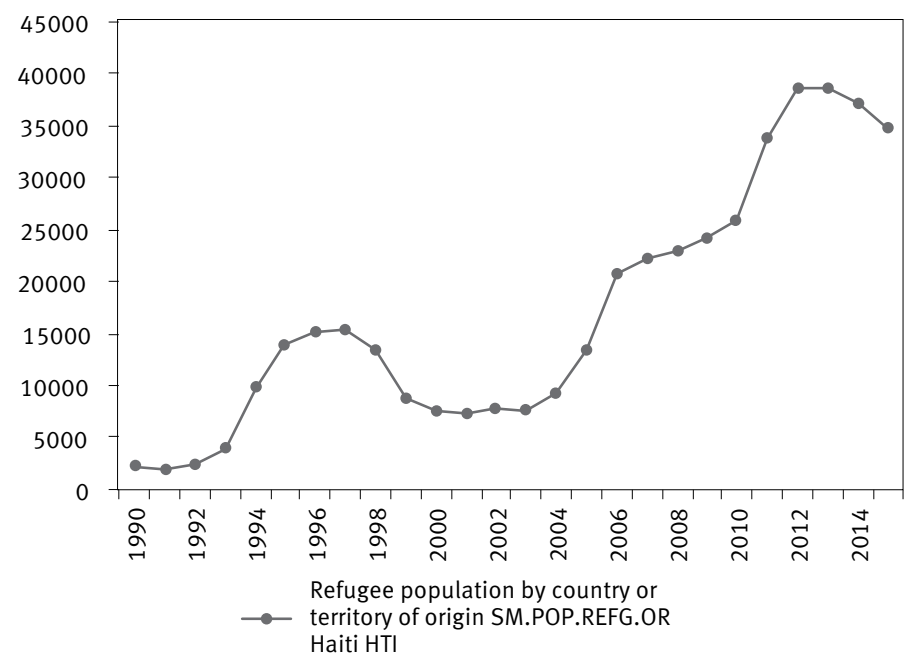

Source: UNHCR.

This multidimensional insecurity provided the background for the remarkable volume of Haitian refugee migration, and its steady growth since the beginning of the 1990s. According to UNHCR data, there were three periods of rapid growth in the volume of refugee flows or assimilated (including refugee-like situations) since 1990: the second half of the 1990s, the 
middle of the last decade, and the 2010-2014 period (Graph 1). The first period followed the phase of the military dictatorship that overthrew Aristide, and was marked by sharp deteriorating living conditions (embargo, etc.). The second period has seen both strong political instability and unprecedented succession of environmental disasters. The average number of refugees remained above 20,000 during the $2006-2010$ period, and exceeded 30,000 during the four years that followed the 2010 earthquake (Graph 1).

\section{The classic pattern of the Haitian diaspora: a migration centered on the North Atlantic}

Contemporary emigration from Haiti has traditionally been heading towards the North for over half a century, primarily to the US, Canada and France, and towards the neighboring countries of the Caribbean basin. The most recent official estimates put the number of Haitian immigrants at 600,000 in the US, 86,000 in Canada, and 40,000 in Metropolitan France. ${ }^{3}$ Other migration flows have developed towards nearby countries, mainly the Dominican Republic where 460,000 of them live, the Bahamas (40,000 migrants) and the French Caribbean (28,000 migrants). Mexico and Venezuela are the main traditional destinations that have received middle-class Haitians of several generations, in the Circum-Caribbean region. ${ }^{4}$

In North America, the US is a privileged destination for Haitian migrants. The long-term inscription of Haiti in the geopolitical orbit of the United States since the occupation period (1915-1934) prepared the grounds for the latter's durable economic, diplomatic and cultural presence in the Caribbean nation (BALCH, 1927). These close historical relations have provided the macro-structural framework behind the flows of political opponents to Duvalier's dictatorship and migrant workers towards the US, through a more open migration legislation after 1965 (STEPICK, 1998; LAGUERRE, 1998). After Canada opened its border to nonEuropean immigration in 1967, Quebec's opening up to qualified francophone immigration has provided new opportunities to educated Haitian middle-classes (AUDEBERT, 2012).

Historical and cultural ties between Haiti, France and its Caribbean territories (French Antilles and Guiana) inherited from colonial and postcolonial legacies, and the economic and educational opportunities migrants and their children may benefit from, explain the direction of a part of these flows towards these destinations. Guiana, Saint Martin, Guadeloupe and Martinique have also served as major steps in lifetime migratory projects, whose ultimate destination was Metropolitan France (AUDEBERT, 2012). Migration channels, based on family and kinship networks, have developed between these multiple French territories throughout the 1970 s and the 1980 s.

In the Dominican Republic, the cross-border migration space initially based on agricultural labor migration, has progressively diversified to include students, and workers in the service industry, tourism and construction. The Haitian migration to the Bahamas

\footnotetext{
${ }^{3}$ Source: US Census American Community Survey 2011-2014, Statistiques Canada Enquête Ménages 2011, INSEE RGP 2010.

${ }^{4}$ Source: World Bank 2015.
} 
emerged in the second half of the 20th century, as part of an international migratory field that has gradually connected the north of Haiti to Florida, and within which the Bahamian archipelago has become a transit place as well as a country of destination.

The geography of Haitian migration, centered on the North Atlantic and the Caribbean, has determined to a large extent the destination of refugee flows.

\section{The geography of the Haitian refugee migration: old patterns and new trends}

Within these migration flows, refugees and asylum seekers constitue specific categories. According to the 1951 Geneva Convention and its 1967 Protocol, the refugee category refers to "any person who owing to a well founded fear of being persecuted for reasons of race, religion, nationality, membership of a particular social group or political opinion, is outside the country of his/her nationality and is unable, or owing to such fear, is unwilling to avail himself/herself of the protection of that country". An asylum seeker is a person who is seeking protection as a refugee and is still waiting to have his/her claim assessed.

Haitian refugees and asylum seekers have been located for the most part in North America and France for many years (Table 1). In 2014, the US, Canada and France have respectively hosted 65 percent, 23 percent and 9 percent of Haitian refugees in the world.

The evolution of refugee flows after the earthquake has been marked by diverging trends, with, on the one hand, the slowing pace of the reception of refugees in the French Caribbean territories, and on the other hand, the relatively open refugee policy in the two North American destinations (Table 1).

TABLE 1

Haitian refugees in the world by host country 2000-2014

\begin{tabular}{|c|c|c|c|c|c|c|c|c|c|c|c|c|c|c|c|}
\hline Country & 2000 & 2001 & 2002 & 2003 & 2004 & 2005 & 2006 & 2007 & 2008 & 2009 & 2010 & 2011 & 2012 & 2013 & 2014 \\
\hline Canada & 439 & 511 & 392 & 413 & 460 & 632 & 783 & 1,295 & 1,410 & 1,662 & 2,906 & 4,963 & 6,798 & 7,872 & 8,422 \\
\hline $\begin{array}{l}\text { Costa } \\
\text { Rica }\end{array}$ & 0 & 0 & 0 & 0 & 0 & 0 & 0 & 31 & 34 & 38 & 38 & 38 & 38 & 38 & 38 \\
\hline Ecuador & 0 & 0 & 1 & 6 & 12 & 14 & 14 & 14 & 14 & 18 & 22 & 24 & 27 & 25 & 22 \\
\hline Germany & 0 & 0 & 16 & 15 & 17 & 7 & 41 & 39 & 41 & 40 & 49 & 47 & 45 & 15 & 15 \\
\hline Mexico & 14 & 14 & 11 & 8 & 7 & 19 & 32 & 70 & 126 & 175 & 182 & 191 & 173 & 175 & 175 \\
\hline $\begin{array}{l}\text { Domin. } \\
\text { Rep. }\end{array}$ & 472 & 0 & 0 & 0 & 0 & 0 & 0 & 0 & 0 & 0 & 595 & 595 & 750 & 716 & 603 \\
\hline $\begin{array}{l}\text { Total } \\
\text { world }\end{array}$ & 7,561 & 7,248 & 7,718 & 7,547 & 9,208 & 13,542 & 20,837 & 22,280 & 23,066 & 24,116 & 25,892 & 33,661 & 38,56 & 38,660 & 37,161 \\
\hline
\end{tabular}

Note: It is advisable to note that Haitian immigrants are not officially considered as refugees in Brazil, Chile and Peru. For this reason, these countries do not appear in the statistics above, although they have become major countries of settlement for Haitian migrants in South America since 2010, as will be discussed later. 


\section{Haitian refugees in the French Caribbean and Guiana}

Over the last five years, 80 percent of asylum applications from Haitian nationals in France have been processed in Guadeloupe, Guiana, Martinique and St. Martin. In a context of tightened asylum policies, the earthquake had only had limited effects on the acceptance of Haitian refugees in France and the evolution of their numbers. According to the French Office for the Protection of Refugees and Stateless Persons (OFPRA, Office Français de Protection des Réfugiés et Apatrides), during the five years after the disaster, only 4.5 percent of Haitian asylum seekers were granted refugee status, one of the lowest rates among all nationalities.

Over half of demands have been approved under the principle of subsidiary protection. Under the Act of December 10, 2003 which introduced significant changes to the right of asylum, the subsidiary protection is granted by French authorities to any individual who does not fulfill the conditions for being granted refugee status and who is exposed in his country to immediate death threat, torture, inhuman treatment or who faces a serious, direct and personal threat to his or her life in a context of generalized violence resulting from a situation of conflict. Persecution of asylum-seekers need no longer come exclusively from the State. The archives of the OFPRA fully demonstrate the relevance of considering the context of multidimensional vulnerability, which accounts for most of the grounds on which the application is based.

Before the earthquake (2000-2010), the reasons invoked under the principle of subsidiary protection had been related to the resurgence of kidnapping, rape and the racket of individuals and businesspeople by armed gangs, especially in Port-au-Prince and in its metropolitan area. In 2010, and in the following two years, the economic, social and security consequences of the earthquake were the first reasons invoked under the subsidiary protection. After 2012, in a context of increasing pressure on the land, the disputes related to inheritance issues or conflicts between neighbors multiplied in rural areas in Southern and Southwestern Haiti as well as in the Artibonite.

The resumption of politically motivated applications to the OFPRA in the aftermath of Marthelly's election in 2011 was, to a large extent, related to threats on political activists' lives from the opposing side. During the entire period, politically motivated applications have emanated from community activists, or former members of political parties and from opponents of the new regime. After the 2014 elections, applications to the refugee status came from activists threatened for having denounced electoral frauds.

\section{Haitian refugees in North America}

In North America, the motivations of Haitian asylum seekers were like those presented to the authorities of the French Antilles and Guiana. However, the requests were much better accepted by the United States and Canada than in the French territories. The granting of refugee status by Canadian authorities, regulated by the Immigration and Refugee Protection 
Act of 2001, remained limited to a few hundred people until the mid-2000s, and then it increased significantly after the earthquake. The presence of Haitian refugees in Canada tripled between 2010 and 2014, positioning the country as the world's second destination, with 8,400 refugees from Haiti in 2014 (Table 1).

Throughout the period, the United States received most of the Haitian refugees in the world. According to the UNHCR, 24,000 Haitian refugees were living in the US in 2014 (Table 1). The contemporary history of Haitian refugees in the United States demonstrates the extent to which official attempts to distinguish between this category and that of economic migrants is a lost cause in many circumstances. The hybrid status of "Cuban Haitian Entrant" created in 1981, by Washington, has allowed newly arrived Haitian boat people to remain legally in the United States without however granting them permanent residence status (STEPICK, 1998). They were neither recognized as refugees nor were they accepted as economic migrants. Yet, this temporary and precarious status permitted later access to permanent residence and the right to work via the IRCA (Immigration Reform and Control Act) amnesty of 1986 . Since 2000, 31,000 Haitians have been granted the status of permanent residents in the United States under the Haitian Refugee Immigration Fairness Act of 1998. Many former Haitian refugees have progressively become economic immigrants.

The Temporary Protected Status (TPS) enacted after the earthquake was designed by the U.S. Administration in January 2010 in response to the "extraordinary and temporary conditions in that country that prevent Haitian nationals from returning to Haiti in safety" in the aftermath of the earthquake.

The experience of Haitian refugees in North America illustrates the remarkable porosity between the refugee category and the ones pertaining to economic migration. The more recent migration to several Latin American countries is also appreciated under this perspective. Although both migration dynamics have been the consequences of a similar macrostructural context in Haiti, its dynamics remains far more marginal in South American national statistics than it is in the French Caribbean and North American countries (Table 1). The explanation for this paradox resides in the specific political treatment of Haitian migrants by officials in the South American countries of destination and transit.

\section{Heading towards South America: a combination of geopolitical and economic forces}

There is little point in trying to neatly determine whether post-earthquake Haitian migrations towards South America are refugee flows or if they have an economic nature, given the complexity of the factors at work. The 2010 cataclysm acted as a mirror and an amplifier of the multiple historico-structural reasons why Haitians have been leaving their country for several generations, as evidenced by the interweaving of geopolitical, economic and environmental forces behind the most recent stages of the phenomenon. 


\section{Macro-structural forces: the geopolitics and geoeconomy of Haitian migration to} South America

Historico-structural theories have analyzed Caribbean migration as labor mobility from the periphery to the center, seen as necessary for capital accumulation in the context of a broader capitalist world-economy (PORTES; WALTON, 1981; SASSEN, 1988). They have also considered the geopolitical dimension of inter-state power relations, within which migratory flows are developed and structured (WALLERSTEIN, 1984; GROSFOGUEL, 1997). These macro-structural forces have indeed provided a major explanation in the Haitian emigration towards North America and the Caribbean (AUDEBERT, 2012), just as they help understand the present dynamics of migration to South America.

At the dawn of the 21 st century, several countries in Latin America, with Brazil standing among them, joined the traditional State powers (the US, Canada, France) on the Haitian geopolitical chessboard. The military presence of these new players, under the banner of the United Nations, marked a milestone in the implantation of their diplomatic and economic interests in Haiti (FERNANDES, 2010; SILVA, 2013).

The United Nations Mission for the Stabilization of Haiti (MINUSTAH) under Brazilian command, established in the country in 2004, had the objective of ensuring safety (especially at election times), supporting state law reforms, and strengthening the capacity of the Haitian State. After the earthquake, the Mission played a major role in securing urban areas, delivering the humanitarian assistance to the camps, repairing infrastructures, and fighting against the cholera epidemic. Having command responsibilities in this mission, and making up 45 percent of the military force, Brazil took on a de facto pre-eminent geopolitical and diplomatic role in the country. Chile, Uruguay and Peru have also provided substantial military contingents, and became new potential destinations for Haitian would-be emigrants (UNITED NATIONS SECURITY COUNCIL, 2015).

The establishment of asymmetric geopolitical and diplomatic relations between Brazil and Haiti has provided an enabling environment for the economic interests of large Brazilian companies, especially in the bioenergy and construction industries (i.e. Construtora OAS). They have also consolidated bilateral relations between the two countries on migration issues, which helped strengthen the Brazilian consular presence in Haiti. This has had direct implications on emigration, with an accelerated processing of visa applications to Brazil.

\section{The articulation of structural forces and individual perceptions}

The theoretical reflection on international migration incorporates three levels of analysis in one framework: the macro-structural level, which includes the political, economic, and cultural structures of the host countries and the countries of origin; the relational mesolevel of transnational communities and social networks (families, religious structures, etc.); and the individual micro-level of values, expectations and migrant resources (FAIST, 1997). 
As per discussed above, the migration issue is at the very core of the conjunction of interests between the Governments of Haiti and Brazil in two areas. First, the expansionist ambitions of Brazil's diplomacy in the region perfectly articulate with Haitian authorities' requests to support stabilization and security in the country. In addition, Brazilian geoeconomic ambitions in the Caribbean meet the needs of the Haitian State to attract foreign investment.

At the micro-analytical level (that of individuals), the Haitian migration issue is also at the heart of the conjunction of several interests. The strong demand from Brazilian (or to a lesser extent Chilean) corporations for low-cost labor in construction, manufacturing, agro-food industry, and low-skilled services, coincided with the search for employment opportunities among Haitians. This quest for overseas employment has become more compelling after 2010, with the devastating blows to the Haitian economy brought about by the earthquake and the two major hurricanes that followed. The Brazilian robust economic growth, sustained by a policy of substantial infrastructure projects (large hydroelectric dams, organization of the World Football Cup and the Olympic Games, etc.), attracted Haiti's potential migrants, for it contributed to build the image of a prosperous Brazilian economy, creating more and better-paying jobs (FERNANDES, 2010; SILVA, 2013; JOSEPH, 2015), in contrast with the perception of the stagnant Northern economies (Europe, North America) as a result of the recent economic recession.

The military, diplomatic and economic presence of Brazil in Haiti strengthened its positive image among Haitians as the nation of football and a country that had, like Haiti, a historical African cultural legacy. In recent years, Brazil has taken a special and unprecedented place in the imagination of the Haitian migrant. In the Haitian value system and mental map of the diaspora (i.e. the potential countries of destination), Brazil occupies an intermediate position between the rich countries of the North, where it is increasingly difficult to enter and where the risk of deportation is higher than before, and the less-valued Caribbean countries, where employment opportunities are less attractive and prejudice towards neighboring Haiti is persistant, especially in the Dominican Republic and the Bahamas (JOSEPH, 2015; AUDEBERT 2012).

This combination of geopolitical and economic factors that account for Haitian migration to South America makes it difficult to categorize migrants as either refugees or mere economic migrants, and calls for the implementation of pragmatic and smart immigration policies that consider these multiple dimensions, as discussed in the next section.

\section{South American national policies and the making of a Haitian migration system}

French social sciences define the regional migration system as the dynamic articulation of migration flows and fields at a broad geographic scale (that of the continent or the sub-continent), whereby destination, transit and settlement countries are interconnected through population movements (SIMON, 1995). The migration field is "the space that 
is traveled up and down by migrants and structured by all of their flows; in the case of international migration, it encompasses all or part of the space of the country of origin, the country of residence and, where appropriate, of the transit country" (SIMON, 2015).

The genesis of the Haitian migration system in South America is based on the complementarity of the migratory functions (transit, settlement, or both) of each country. The diversity of state migration policies embodies the distinct approaches of the very nature of Haitian migration. While some states have hybrid migration policy approaches that consider the multidimensional vulnerability of the source country (e.g. the humanitarian approach of Brazil and Ecuador), other receiving states have adopted a first and foremost economic approach for these migratory movements (e.g. Peru, Chile).

Ecuador, Peru and Chile: three secondary destinations with diverging migration policies

Within the Haitian migration system in Latin America, Ecuador plays a distinct role as the main gateway for Haitian migration towards neighboring Peru and Brazil. In Ecuador, the introduction of a visa waiver for Haitian citizens - and more generally for Caribbean and Latin American nationals - in 2008, was at the origin of the first phase of the Haitian migration boom between 2008 and 2009. The regularization of Haitian immigrants and their spouses and children following the earthquake, via the Executive Decree No. 248 of February 2010 (non-immigrant visa 12-XI), has led to a second, more substantial, migration wave after 2010. Ecuador has then become both a destination country and a transit territory towards other destinations further south, that still allowed entry on their territories with a tourist visa in 2010 (Peru, Chile, Argentina). In 2013, Ecuador recorded the entry of 14,000 Haitians, whose profile was comparable to that of the Haitian migrants that entered in Brazil during the same period. Eighty percent were men and young adults between 20 and 39 years, mostly administrative workers, artisans, laborers, and students (INEC, 2013). Ninety-two percent of Haitian nationals entered with a tourist visa for 3 months, most of them with the intention to pursue the migration to Brazil (INEC, 2013).

In parallel, Peru officially recorded the entry of nearly 3,000 Haitian "tourists" between 2010 and 2012, a figure that probably underestimated by half the actual flow of migrants entering the country. The subsequent requirement of visas for Haitians before they can enter Peru since 2012 has made migrants in transit more vulnerable to smuggling and abuse on the part of the Peruvian police and local population, without yet contributing to migration flow reductions (VASQUEZ et al., 2014). The position of Peru sharply contrasts those from Ecuador and Bolivia, with active policies against smuggling.

Whereas Ecuador and Peru remain transit countries in the Haitian migration field, Chile has clearly become a country of settlement. Chile has fully taken on its new function as a host country for Haitians, by openly promoting contract labour migration. This partly explains why Haitian nationals make up only 0.3 percent of deportees from Chile (MIGRACIONES CHILE, 2016, p. 185, 189). By contrast with the Dominican Republic or Mexico, virtually no Haitian has recently applied for a refugee status in Chile. Most Haitian migrants have 
entered the country with a temporary visa, mainly through a two-year labor contract with a Chilean business, at the end of which they may apply for permanent residence. Within the four-year period that followed the earthquake, 10,000 Haitians have been granted a legal status in Chile and over 1,500 of them have benefited from permanent residence (MIGRACIONES CHILE, 2016), most dwelling in the capital city Santiago de Chile.

\section{Southern Brasil: the new epicenter of the Haitian diaspora in South America}

Often described as liberal and accommodating after 2010, Brazil's migration policy towards Haitian newcomers has been driven by the economic interests of the Brazilian corporate sector, as well as the acknowledgment of the complex and hybrid nature of this migration after the earthquake and the following hurricanes that have affected the Haitian economy. In response to the first arrivals in Brazil (2010-2012), Haitians have been allowed to apply for asylum, a legal process that has offered temporary access to the local employment market. Yet the situation of most Haitians did not fit in the Refugee category as defined by the Geneva Convention.

To resolve this contradiction, the Federal government established a Humanitarian visa in 2012 in response to the specific situation of Haitians (Normative Resolution 97 - NR97). Another reason for this requiescence by the authorities has been the fight against the organization of clandestine migratory routes and the coyotes (NIETO, 2014). The granting of a legal status to newcomers has been the crucial step that opened the way to their mobility from the Amazonian states (Amazonas, Acre) to Southeastern and Southern states (Sao Paulo, Santa Catarina, Rio Grande do Sul, Parana) of Brazil, and to their long-term incorporation into the employment market. The year 2013 constituted a new turning point, with further migration legislation mollification - e.g. the RN 102 repealed the quota of 1,200 visas granted by the Brazilian consulate in Haiti, and the RN 97 validity period was extended (FERNANDES; GOMES DE CASTRO, 2014).

At the local level, the Amazonian states situated on the migration routes, such as Acre, provided essential support to newly arrived migrants from Haiti. In the early years, local authorities responded to migrants' needs in many fields, including accommodation, health care and even transit to other Brazilian states. Simultaneously, many corporations from Southern Brazil started to recruit Haitian workers directly at the source, in the Amazonian states.

Since 2013, the RN 97 has been extended on an annual basis through four successive resolutions: RN 106 in 2013, RN 113 in 2014, RN 117 in 2015, and RN 123 in 2016. From 2012 to 2016, 48,000 Haitian immigrants have been granted a humanitarian visa at Brazilian Embassies abroad (mainly in Haiti and Ecuador), 12 percent of whom managed to do so for family reunification purposes. Beneficiaries of the humanitarian visa can remain in Brazil for five years. In the meantime, according to the CNIg (Conselho Nacional de Imigração), over 50,000 undocumented Haitians in Brazil have been granted permanent residence under the Normative Resolution 27 (Table 2). Permanent residence status enables the incorporation into the formal labor market and opens access to basic social services. 
TABLE 2

Number of permanent residence permits granted to Haitians nationals by Brazil under the RN 27 2011-2015

\begin{tabular}{cccccc}
\hline Year & 2011 & $\mathbf{2 0 1 2}$ & $\mathbf{2 0 1 3}$ & $\mathbf{2 0 1 4}$ & $\mathbf{2 0 1 5}$ \\
\hline $\mathrm{N}$ & 708 & 4,825 & 2,069 & 1,890 & 41,632 \\
\hline
\end{tabular}

Source: Conselho Nacional de Imigração - MTE, 2015.

TABLE 3

Number of humanitarian visas granted to Haitian nationals by Brazil under RN 97 2012-2016

\begin{tabular}{ccccccc}
\hline Year & $\mathbf{2 0 1 2}$ & $\mathbf{2 0 1 3}$ & $\mathbf{2 0 1 4}$ & $\mathbf{2 0 1 5}$ & $\mathbf{2 0 1 6}$ (Jan-May) & Total \\
\hline $\mathrm{N}$ & 1,387 & 6,296 & 10,188 & 17,507 & 12,983 & 48,361 \\
\hline
\end{tabular}

Source: Ministério das Relações Exteriores, 2016; cited in OIM-CNIg (2016).

This legal context resulted in the creation of complex migration routes across South America, as described in many studies (SILVA, 2012, 2013; NIETO, 2014; BERNAL CARRERA, 2014; FERNANDES; DA CONSOLAÇAO GOMES DE CASTRO, 2014; VASQUEZ; BUSSE; IZAGUIRRE, 2014; JOSEPH, 2015). The first segment of the route leads to Santo Domingo, where migrants take a flight to Panama and Ecuador (Quito or Guayaquil). The next segment leads to Peru and runs through the country (Lima, Cuzco, Puerto Maldonaldo, Inapari) all the way to the Brazilian border state of Acre (Brasileia). Other land routes to Brazil also pass through Bolivia or Northern Peru (Iquitos, Pucalipa).

Most migrants subsequently continue on to the southern states, towards the country's economic heartland in search for employment opportunities. According to the RAIS/ MTE, most of the 30,000 Haitian nationals who had a work permit in Brazil in 2014 were concentrated in the three states of Santa Catarina (25 percent), Sao Paulo (24 percent) and Parana (22 percent). They have generally joined the labor market at the bottom of the ladder, mainly in construction, poultry and meat slaughtering and processing, restaurants and bars, farming (apple production), housekeeping and cleaning. ${ }^{5}$

\section{Conclusion}

The articulation of socio-economic, political and ecological issues in the origin country has amplified the dynamics of emigration and led a few governements to deal with Haitian migration along lines other than binary ones, by creating an intermediary legal status between the refugee category and economic migration. Such a response takes into consideration the multidimensional vulnerability of the Haitian society. Notwithstanding contextual specificities, putting into perspective old migration patterns with new trends reveals some continuity across time and space in the Haitian diaspora.

\footnotetext{
$\overline{5}$ Source : Ministério do Trabalho e Previdência Social.
} 
The emerging Haitian migration field in South America has much in common with the ones that were established elsewhere in the Americas, from Haiti to the Bahamas and Florida in the 1960s and 1970s and to the French Antilles and Guiana in the 1970s and 1980s.

The first common feature resides in the effective operation of the migration channels through what is commonly referred to in Haiti as teledjol, that is, the circulation of information on employment opportunities in the settlement societies (i.e. Southern Brazil, South Florida) disseminated by established immigrants to family and kinship in Haiti. Secondly, in a federal context, the dialogue between the Federal government (Washington, Brasilia) and the federated states (Acre, Amazonas; Florida) was in both cases decisive in the definition of a migration policy that considers the complex nature of migration flows. Through the Cuban Haitian Entrant Status, that paved the way for the establishment of the Haitian Florida network three decades ago, and Brazil's recent Normative Resolution 97 (RN 97) that ushered in the migrant connection between Haiti and Southern Brazil, the authorities of the destination countries both acknowledged the intermingling of political and economic dimensions of these migratory flows.

Another shared feature that explains the continuity and strength of both migration networks is the response they have provided to the local economies' need for inexpensive labor (agriculture, construction and tourism in Florida, agriculture, meatpacking and construction in Southeastern Brazil). Thus, the Haitian migration field that connects Haiti to Southern Brazil through Panama, Ecuador and Peru is rather common in its structuring and functioning, though atypical vis-à-vis regular migratory routes.

Ultimately, the emergence of new migration routes and fields mark a new stage in the expansion and structuring of Haiti's international migration space in the Americas. In this migration system, the migration networks in North America, the Caribbean and South America are increasingly intertwined, and the distinction between refugees and economic migrants rarely stand up to the field observations.

Undocumented migration develops when immigrants do not fit in the categories of existing migration legislation. In response, governments have two alternatives. Firstly, a repressive migration policy aiming to be dissuasive was the option that was most implemented in Peru over the last years; secondly, an open migration policy following the 2010 earthquake was adopted by the governments of Brazil and Ecuador. The latter is characterized by the implementation of an innovative legislation that has translated itself into the creation of a humanitarian visa. This was completed by a large-scale regularization policy, as a way to deter human trafficking and to favor the integration of immigrants to the local economy, in particular in 2015 when 40,000 Haitians were granted permanent residence. Another option could be the design of a complementary legislation that would promote the circulation of workers between Haiti and Brazil, by the granting of temporary visas in industries such as construction and food-processing.

However, despite its importance, this migratory phenomenon is not a one-way linear dynamics. Similar to other older migratory fields observed in other spaces of the Haitian 
diaspora, it is reversible and subject to new geographical orientations, depending on the economic situation in the settlement country. Given the economic recession experienced in Brazil at present, unskilled workers are the most affected. While remaining a country of settlement, Brazil may also become a transit destination for Haitian migration towards other destinations in the Americas. A Haitian migratory corridor has recently emerged from Brazil towards Central America, Mexico and the US, with the effect of the development of a Haitian presence in Southern California.

\section{References}

ANGLADE, G. Atlas critique d'Haïti. Montréal: Centre de Recherches Caraïbes de l'Université de Montréal, 1982a.

Espace et liberté en Haïti. Montréal, 1982b.

AUDEBERT, C. La diaspora haïtienne: territoires migratoires et réseaux transnationaux. Rennes: Presses Universitaires de Rennes, 2012.

BALCH, E. G. Occupied Haiti. New York: The Writers Publishing Company, 1927.

BASCH L.; SCHILLER, N. G.; BLANC, C. S. Nations unbound: transnational projects, postcolonial predicaments and detteritorialized Nation-States. Routledge, 1993.

BARTHELEMY G. L'univers rural haïtien: Le pays en dehors. Paris: L'Harmattan, 1990.

BERNAL CARRERA, G. La migracion haitiana hacia Brasil: Ecuador, pais de transito. In: Organización Internacional para las Migraciones, La migración haitiana hacia Brasil: características, oportunidades y desafíos. Buenos Aires: OIM, 2014, p. 67-82 (Cuadernos Migratorios, n. 6).

COGO, D. Haitianos no Brasil: comunicação e interação em redes migratorias transnacionais. Chasqui. Revista Latinoamericana de Comunicacion, n. 125, p. 23-32, 2014.

FAIST, T. The crucial meso-level. In: HAMMAR, T. et al. (Ed.). International migration, immobility and development. Multidisciplinary perspectives. Berg: Oxford, 1997. p. 187-217.

FERNANDES, J. S. Operação Haiti: ação humanitária ou interesse político para o Brasil? Conjuntura Internacional, n. 22, p. 1-4, 2010. Available in: 〈http://www.pucmg.br/imagedb/conjuntura/ CNO_ARQ_NOTIC20100323112219.pdf〉. Accessed on: 10 July 2016.

FERNANDES, D.; CASTRO, M. C. G de. A migração haitiana para o Brasil: resultado da pesquisa no destino. In: ORGANIZACIÓN INTERNACIONAL PARA LAS MIGRACIONES. La migración haitiana hacia Brasil: características, oportunidades y desafíos. Buenos Aires: OIM, 2014. p. 51-66 (Cuadernos Migratorios, n. 6).

GROSFOGUEL, R. Migration and geopolitics in the Greater Antilles: from Cold War to Post-Cold War. Review, v. 20, n. 1, p. 115-145, 1997.

INEC - Instituto Nacional de Estadistica y Censos. Anuario de estadisticas de entradas y salida internacionales. Quito: Direccion de Estadisticas Sociodemograficas, 2013.

INTERNATIONAL ORGANIZATION FOR MIGRATION. World migration report 2015. Migrants and cities: new partnerships to manage mobility. Geneva: IOM, 2015.

JACKSON, R. Geographies of the Haitian diaspora. New York: Routledge, 2011.

JOSEPH, H. Diaspora. As dinâmicas da mobilidade haitiana no Brasil, no Suriname e na Guiana Francesa. 2015. 430 f. Tese (Doutorado em Antropologia Social) - Universidade Federal do Rio de Janeiro, Museu Nacional, Rio de Janeiro, 2015. 
LAGUERRE, M. Diasporic citizenship: Haitian Americans in transnational America. New York: St. Martin's Press, 1998.

LUNDAHL, M. The Haitian economy: man, land and markets. New York: St. Martin's Press, 1983.

MALO CORRAL, N. Entre el drama y la integracion: inmigrantes y refugiados haitianos en el Ecuador. Quito: Pontificia Universidad Catolica del Ecuador, Disertacion previa a la obtencion del titulo de sociologo con mencion en desarollo, 2013.

MIGRACIONES CHILE. Migracion en Chile 2005-2014. Santiago: Departamento de Extranjeria y Migracion del Ministerio del Interior y Seguridad Publica del Chile, 2016.

NIETO, C. Migracion haitiana a Brasil. Redes migratorias y espacio social transnacional. Buenos Aires: CLASCO, 2014 (Coleccion Estudios sobre las Desigualdades).

OIM - Organização Internacional para as Migrações; CNIG - Conselho Nacional de Imigração; MINISTÉRIO DO TRABALHO. Imigração haitiana no Brasil: características sociodemográficas e laborais na Região Sul e no Distrito Federal. Available in: 〈http://obmigra.mte.gov.br/index.php/ publicacoes-obmigrà. Accessed on: 05 Jan. 2017.

PORTES, A.; WALTON, J. Labor, class and the international system. New York: Academic Press, 1981.

ROJAS PEDEMONTE, N. et al. Migracion haitiana en Chile. Santiago de Chile: Departamento de Extranjería y Migración, 2016 (Boletin informativo, n. 1). Available in: 〈www.extranjeria.gob.cl/ media/2016/09/boletin-1.pdf>. Accessed on: 01 May 2017.

SASSEN, S. The mobility of capital and labor: a study in international investment and labor flow. Cambridge: Cambridge University Press, 1988.

SILVA, S.A. "Aqui começa o Brasil”. Haitianos na triplice fronteira e Manaus. In: SILVA, S. A. (Ed). Migrações na Pan-Amazônia. São Paulo: Hucitec/FAPEAM, 2012. p. 300-332.

Brazil, a new Eldorado for immigrants? The case of Haitians and the Brazilian immigration policy. Urbanities, v. 3, n. 2, p. 3-18, 2013.

SIMON, G. Géodynamique des migrations internationales dans le monde. Paris: PUF, 1995. Colin, 2015.

Dictionnaire des migrations internationales. Approche géohistorique. Paris: Armand

STEPICK, A. Pride aginst prejudice: Haitians in the US. Boston: Allyn \& Bacon, 1998.

UNITED NATIONS SECURITY COUNCIL. Report of the Secretary-General on the UN stabiliztion mission in Haiti, 2015. Available in: 〈http://www.un.org/en/ga/search/view_doc. asp?symbol=S/2015/667 . Accessed on: 20 May 2016.

VASQUEZ T.; BUSSE, E.; IZAGUIRRE, L. La migracion haitiana en Peru y su transito hacia Brasil. In: ORGANIZACIÓN INTERNACIONAL PARA LAS MIGRACIONES. La migración haitiana hacia Brasil: características, oportunidades y desafíos. Buenos Aires: OIM, 2014. p. 83-105 (Cuadernos Migratorios, n. 6).

WALLERSTEIN, I. The politics of the world economy. Cambridge: Cambridge University Press, 1984.

\section{About the author}

Cedric Audebert is doctor in Geography. Director of the MIGRINTER Research Center, Université de Poitiers. Permanent researcher at the CNRS (Centre National de la Recherche Scientifique). 


\title{
Contact address
}

\author{
MIGRINTER - CNRS \\ Maison des Sciences de l'Homme et de la Société de Poitiers \\ 5 rue T. Lefebvre - TSA 21103 \\ F-86073 Poitiers Cedex, Francia
}

\section{Resumo}

A geodinâmica recente da migração haitiana nas Américas: refugiados ou migrantes econômicos?

Depois de apresentar o contexto de migração específico do Haiti e seus aspectos multidimensionais, o artigo demonstra que a geografia da diáspora haitiana explica, em grande medida, a localização dos refugiados e requerentes de asilo na América do Norte e nos territórios franceses do Caribe. Aborda-se a relação entre a evolução da política de migração e o desenvolvimento de novas rotas de migração em direção à América do Sul, onde o reconhecimento do caráter multidimensional dessa imigração abriu caminho para a legalização da presença haitiana, particularmente no Brasil. As funções migratórias complementares do Equador, Peru, Brasil e Chile desenham um novo sistema de migração regional centrado no Sudeste e no Sul do Brasil. Este emergente espaço de migração Sul-Sul faz parte de um sistema migratório haitiano mais amplo, que conecta a América do Sul com a América do Norte e o Caribe.

Palavras-chave: Política de migração. Refugiados. Haitianos. América Latina. América do Norte, o Caribe.

\section{Resumen}

La geodinamica reciente de la migracion haitiana en las Americas: refugiados o migrantes econômicos?

Habiendo presentado el contexto migratorio especifico de Haiti y sus aspectos multidimensionales el articulo mostrará que la geografía de la diáspora explica en gran medida la ubicación de los refugiados y solicitantes de asilo en América del Norte y el Caribe francés. Después, exploraremos la relación entre la evolucion de las políticas migratorias y el desarollo de nuevas rutas de migración hacia América del Sur, donde el reconocimiento del carácter polifacético de esta migración ha abierto el camino para la legalización de la presencia haitiana, especialmente en Brasil. El caracter complementario de las funciones migratorias del Ecuador, Peru, Brasil y Chile define un nuevo sistema migratorio regional centrado en el sureste y el sur de Brasil. Este espacio migratorio Sur-Sur en gestación forma parte de un sistema migratorio haitiano más amplio que conecta América Latina a América del Norte y el Caribe.

Palabras clave: Política migratoria. Refugiados. Haitianos. América Latina. América del Norte, el Caribe. 
